\title{
Penerapan Model Pembelajaran Picture And Picture Berbantuan Kelompok Undian Untuk Meningkatkan Hasil Belajar Siswa Di Smp Negeri 2 Wagir
}

\author{
Angela Merici $^{1, *}$, Triwahyudianto ${ }^{1}$, Nelya Eka Susanti, ${ }^{1}$ \\ ${ }^{1}$ Program Studi Pendidikan Geografi Universitas Kanjuruhan Malang, \\ Malang 65148, Indonesia \\ Email: *angelamerici051@gmail.com¹, u.diant@yahoo.com,nelyaeka@unikama.ac.id
}

Dikirim : 19 Maret 2019

Diterima: 29 Maret 2019

\begin{abstract}
Abstrak: Penelitian ini dilatarbelakangi oleh rendahnya hasil belajar, pembelajaran yang cenderung pasif karena siswa tidak hanya mampu memahami materi yang dijelaskan secara abstrak tetapi perlu dibantu dengan menggunakan media untuk bisa memahami maksud dari materi yang diajarkan. Berdasarkan hasil observasi dan terdapat masalah pada hasil belajar siswa maka peneliti menerapkan model yang dapat meningkatkan hasil belajar yaitu Picture and Picture Berbantuan Kelompok Undian. Jenis penelitian ini yaitu penelitian tindakan kelas yang dikembangkan oleh Kemmis and Mc. Taggard (2006). Penelitian ini dilaksanakan di SMP Negeri 2 Wagir kelas VIII B tahun ajaran 2018/2019 yang terdiri 33 siswa dengan 16 perempuan dan 17 laki-laki. Instrumen yang digunakan dalam penelitian ini yaitu lembar kerja siswa dan lembar catatan lapangan. Berdasarkan hasil penelitian yang sudah dilaksanakan menunjukan hasil siklus I dan siklus II mengalami peningkatan hasil belajar secara signifikan.
\end{abstract}

Kata Kunci : Picture And Picture, Kelompok Undian, Hasil Belajar.

\begin{abstract}
This research is motivated by the low learning outcomes, passive learning because students are not only able to understand the material explained in the abstract but need to be helped by using the media to understand the purpose of the material being taught. Based on the results of observations and there are problems in student learning outcomes, the researcher applies a model that can improve learning outcomes, namely Picture and Picture Assisted by Lottery Groups. This type of research is class action research developed by Kemmis and Mc. Taggard (2006). This research was carried out in the Wagir 2 Public Middle School class VIII B 2018/2019 academic year consisting of 33 students with 16 women and 17 men. The instruments used in this study were student worksheets and field notes. Based on the results of research that has been carried out shows the results of the first cycle and second cycle experienced a significant increase in learning outcomes.
\end{abstract}

Keywords: Picture And Picture, Lottery Groups, Learning Outcomes.

\section{Pendahuluan}

Pengalaman mengajar mata pelajaran IPS di SMP Negeri 2 Wagir masih terdapat permasalahan yang berkaitan dengan hasil belajar. Pembelajaran dengan metode ceramah seringkali menjadi pemicu kurangnya hasil belajar siswa, jelas sekali karena siswa hanya mendengarkan apa yang disampaikan guru secara abstrak sehingga siswa susah untuk dipahami. Menurut Sobry Sutikno (dalam Utin Kurnia, Herkulana. 2013. 6) mengatakan bahwa usaha pencapaian hasil belajar siswa dipengaruhi oleh faktor internal seperti jasmaniah sedangkan faktor ekternal yaitu faktor keluarga, sekolah dan masyarakat.

Masalah pembelajaran inilah yang perlu untuk diselesaikan dan dicarikan solusi untuk mengatasi kurangnya hasil belajar siswa dalam pembelajaran IPS khusus pada kelas VIII B, adapun alasan lain karena kurangnya sarana-prasarana sekolah seperti perpustakan terbatas pada pemasukan buku-buku pegangan siswa, alat pendukung pembelajaran lainnya seperti 
LCD, atlas, gambar-gambar yang sesuai dengan materi IPS. Sehingga tugas guru adalah menerapkan model pembelajaran yang mampu merangsang pemikiran dan dapat meningkatkan hasil belajar yang tertuang pada faktor eksternal.

Refleksi awal menunjukan kurangnya hasil belajar siswa dikarenakan penggunaan model pembelajaran yang kurang mampu merangsang cara belajar siswa serta banyaknya bahasa asing yang sukar untuk diingat sehingga, sulit untuk membuat siswa memahami materi dan akan berpengaruh pada daya ingat. Penggunaan model ceramah merupakan model yang mudah untuk diterapkan dan tidak memerlukan banyak tenaga untuk menyiapkan media seperti halnya model pembelajaran lain, tetapi model ini sering digunakan dan masih terdapat siswa yang hasil belajarnya kurang, siswa dianggap sebagai objek pasif, hanya kegiatan tanya jawab dan mencatat dan materi bisa guru kaitkan dengan kehidupan sehari-hari. Sejalan dengan pemikiran Narulita (Dalam Utin Kurnia, 2013, 3) mengatakan bahwa model ceramah adalah sebuah interaksi antara guru dan siswa melalui alat komunikasi lisan. Sehingga, sangat terlihat jelas apabila pembelajaran hanya diberikan secara lisan atau abstrak tanpa disertai gambar maka siswa akan susah memahami materi.

Penentuan model dalam pembelajaran sangat menentukan keberhasilan dalam pembelajaran. Kegiatan pembelajaran pada dasarnya untuk meningkatkan tingkat pengetahuan siswa tentang materi yang diajarkan, berbagai interaksi dalam pembelajaran dan pengalaman siswa dalam belajar, alasan ini menjadi dasar untuk pembentukan nilai kognitif siswa, dengan penekanan pada pembelajaran yang mampu membuat siswa memahami materi yang diajarkan.

Maka peneliti berusaha melakukan penanganan dalam masalah pembelajaran ini dengan menggunakan model Picture and Picture berbantuan Kelompok Undian. Alasan peneliti menggunakan model ini, karena pada model ini siswa akan berperan aktif dalam mengemukakan pendapat, sehingga dapat meningkatkan keterampilan berkomunikasi dan bisa terukur bahwa siswa memahami materi, bertanggung jawab atas jawaban yang diberikan, kemampuan mengingat dengan melihat gambar dan menulis, kemampuan mengingat siswa dapat lebih mudah diterapkan dengan menggunakan model ini selain didukung dengan gambar, model ini juga bisa merangsang otak untuk mengingat karena disertakan dengan gambar berwarna.

Model pembelajaran Picture and Picture Berbantuan Kelompok Undian merupakan sebuah model yang dapat meningkatkan hasil belajar. Alasannya, model pembelajaran Picture and Picture menerangkan materi dengan bantuan media gambar, sehingga jelas bahwa materi yang diterima oleh siswa tidak hanya bahan abstrak saja tetapi dibuktikan dengan gambar dan ini akan merangsang siswa untuk mau belajar berbicara dalam mengemukakan pendapat terkait penyusunan gambar secara logis sesuai dengan sintak model pembelajaran Picture and Picture.

Tujuan pengabungan model ini dengan menggunakan Berbantuan Kelompok Undian, untuk bisa mengelolah waktu dengan siswa yang heterogen dengan tujuan agar semua siswa mendapat bagian dalam menyusun gambar sesuai dengan pertanyaan yang diberikan oleh guru serta mau bertaanggungjawab dan disiplin terhadap durasi waktu yang diberikan karena di dalam undian terdapat nomor undian dan durasi waktu setiap siswa dalam menjawab pertanyaan. Sesuai dengan pendapat Carl (dalam Sudjana 2002.21) mengatakan bahwa "hasil belajar siswa di sekolah 70\% dipengaruhi oleh kemampuan siswa dan 30\% dipengaruhi olelh lingkungan". Dengan demikian model pembelajaran ini dapat merangsang otak dengan memahami materi dengan bantuan gambar. 


\section{Metode Penelitian}

Penelitian ini menggunakan rancangan Penelitian Tindakan Kelas (PTK), dengan menggunakan metode statistik deskriptif, dengan mengikuti rancangan model Kemmis dan Mc. Taggard yang terdiri dari 4 tahap yaitu prencanaan, pelaksanaan, observasi, dan refleksi. Penelitian ini digunakan untuk memperbaiki kualitas proses pembelajaran khususnya pada peningkatan hasil belajar siswa. Subjek penelitian yaitu siswa kelas VIII B SMP Negeri 2 Wagir yang berjumlah 33 siswa terdiri dari 16 perempuan dan 17 laki-laki. Instrumen yang digunakan pada penelitian ini yaitu lembar kerja soal siswa dan lembar catatan lapangan. Pengumpulan data didapat dari skor hasil belajar siswa dan temuan lapangan.

\section{Pengumpulan Data}

Data yang diambil merupakan skor hasil belajar setelah menerapkan model pembelajaran dengan memberikan tes kepada siswa sebagai bahan evaluasi semua rangkaian pembelajaran, dan catatan temuan lapangan berkaitan dengan kelebihan dan kekurangan dalam penerapan model pembelajaran Picture And Picture berbantuan Kelompok Undian dalam meningkatkan hasil belajar siswa.

\section{Analisis Data}

Peneliti menggunakan 2 siklus dengan pembagian siklus I peneliti menjelaskan materi pembelajaran kemudian siklus II peneliti memberikan tes sebagai evaluasi keterlaksanaan model mampu meningkatkan hasil belajar siswa. Selama penerapan model peneliti memperhatikan kelebihan dan kekurangan dalam penerapan model sehingga akan dituangkan dalam catatan temuan lapangan sehingga dapat meningkatkan dan memperbaiki kekurangan dalam penerapan model pembelajaran yang digunakan.

\section{Hasil Penelitian Dan Pembahasan}

\section{Pra Tindakan}

Berdasarkan hasil pra tindakan yang menenmukan masalah pemicu kurangnya hasil belajar, kurangnya daya tangkap siswa terhadap materi, kurangnya media yang membantu membawa siswa untuk mengetahui keadaan nyata suatu materi. Menurut Rasyid (dalam Juniarti. 2008. 67) guru dan pembelajaran dapat menjadikan informasi hasil penilaian sebagai dasar dalam menentukan langkah-langkah pemecahan masalah, sehingga mereka dapat memperbaiki dan meningkatkan hasil belajarnya.

Kesulitan pada hasil belajar yang dialami siswa siswa kelas VIII B SMPN 2 Wagir terlihat dari hasil nilai rata-rata yang kurang dari Kriteria Ketuntasan Minimal (KKM) yang ditetapkan disekolah yaitu 75. Dari 33 siswa yang terdiri dari 17 siswa laiki-laki dan 16 siswa perempuan, nilai hasil ulangan pertama yang dilaksanakan secara tertulis hanya 9 siswa atau $27,27 \%$ yang bisa menjawab pertanyaan diatas nilai KKM, sedangkan 24 siswa atau 72,75\% belum bisa mengerjakan tes yang peneliti lakukan tantang materi Interaksi Keruangan. Hasil data ini sudah jelas sekali hasil belajar yang kurang sehingga dapat meyakinkan pendapat Rasyid (dalam juniarti 2008. 67) tentang peran guru harus ada untuk meningkatkan hasil belajar siswa. 


\section{Siklus I}

Pada tahap siklus I pertemuan pertama ( 2 x 40 Menit) peneliti memberikan tindakan dengan menerapkan model pembelajaran Picture and Picture Berbantuan Kelompok Undian pada materi faktor penghambat mobiltas sosial dan saluran mobilitas sosial. Pada tahap siklus I untuk pertemuan pertama, peneliti membaginya dalam beberapa tahap sesuai rancangan penelitian Kemmis dan Mc. Taggart: yaitu 1) Perencanaan tindakan dengan menyiapkan semua perangkat pembelajaran, instrumen yang berkaitan dengan penelitian ini. 2) Tahap pelaksanaan tindakan dengan pertemuan pertama peneliti memberikan materi dengan menerapkan model pembelajaran Picture and Picture Berbantuan Kelompok Undian sesuai dengan panduan Rancangan Pelaksanaan Tindakan (RPP) dengan bantuan lembar instrumen catatan temuan lapangan yang diberikan kepada observer. Pada tahap awal kegiatan inti guru menyajikan materi sesuai dengan panduan RPP, pada tahap kedua peneliti membagikan undian kepada siswa yang berisi nomor undian dan jumlah waktu dalam menjawab pertanyaan, pada tahap ketiga pembelajaran setiap kelompok hasil undian dengan menyusun gambar sesuai dengan materi dan menjawab pertanyaan, dan tahap kelima peneliti memberikan penghargaan terhadap berupa penambahan nila dengan tujuan memberi motivasi. 3) Pada tahap ini, peneliti bersama siswa memberikan kesimpulan pada seluruh rangkaian kegiatan pembelajaran.

Pada pertemuan kedua siklus I ( 2 x 40 Menit) peneliti memberikan tes tentang materi yang telah diberikan sebelumnya. Pada tahap pendahuluan guru memberi salam dan memberikan waktu siswa untuk belajar, review bersama guru tentang materi yang sudah diajarkan sebelumnya. Pada tahap kegiatan inti guru membagi soal uraian kepada 33 siswa, selama 50 menit siswa mengerjakan soal kemudian di cek kembali jika dalam menjawab ada kesalahan. Pada tahap penutup semua lembar kerja dikumpulkan dan guru sedikit mereview setiap jawaban soal bersama siswa dan akhir waktu guru dan siswa berdoa dan menyampaikan salam penutup.

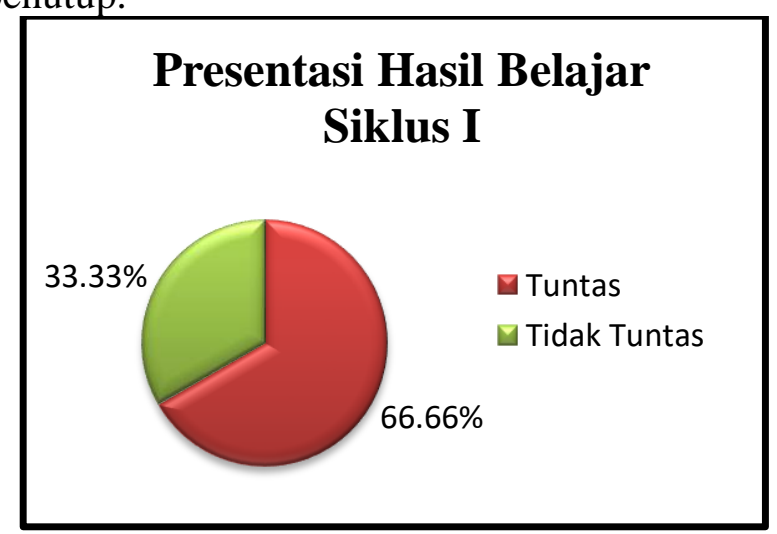

Diagram 1. Presentasi Hasil Belajar Siklus I

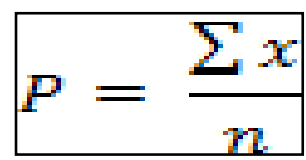

$\mathrm{P}=$ Rata-rata nilai

$\sum \mathrm{x}=$ Jumlah nilai keseluruhan

$\mathrm{n}=$ Jumlah siswa 
Table 1. Penentuan Keberhasilan Hasil Belajar

\begin{tabular}{ccc}
\hline Nilai Interval & Huruf & Kriteria \\
\hline$\geq 85$ & A & Sangat baik \\
\hline $75-84$ & B & Baik \\
\hline $65-74$ & C & Cukup \\
\hline $55-64$ & D & Kurang \\
\hline$\leq 54$ & E & \\
\hline Sumber:Adaptasi Jihad dan Setiorini $(2007: 136)$ & \\
& $P=\frac{2.560}{33}=77,57$
\end{tabular}

Berdasarkan hasil observasi peneliti terkait hasil belajar siswa SMPN 2 Wagir masih sangat rendah, sehingga dengan alasan ini peneliti akan meningkatkan hasil belajar pada mata pelajaran IPS materi mobilitas sosial dengan cara menenrapkan model pembelajaran Picture and Picture berbantuan kelompok undian. Siklus I peneliti menerapkan model pembelajaran ini pada dan pertemuan kedua akan diberikan tes, dengan hasil yang kurang signifikan. Data hasil belajar dari 33 siswa yang didapatkan hanya ada 22 siswa atau 66,66\% yang mendapatkan nilai di atas 75 Kriteria Ketuntasan Minimum (KKM), dan 11 siswa atau $33,33 \%$ yang mendapatkan nilai di bawa KKM, dengan soal tes materi mobilitas sosial, faktor pendorong, penghambat dan saluran mobilitas sosial.

\section{Siklus II}

Siklus II pertemuan pertama ( 2 x 40 Menit) peneliti memberikan tindakan dengan menerapkan model pembelajaran Picture and Picture Berbantuan Kelompok Undian pada materi cara melakukan mobiltas sosial, proses terjadinya mobilitas sosial dan dampak mobilitas sosial. Pada tahap siklus I untuk pertemuan pertama, peneliti membaginya dalam beberapa tahap sesuai rancangan penelitian Kemmis dan Mc. Taggart sesuai dengan pembagian pada siklus I yang terdiri dari pertemuan pertama tahap pendahuluan, kegiatan inti dan penutup dilakukan berdasarkan panduan RPP, hanya saja sesuai dengan hasil temuan lapangan terkait kekurangan model peneliti menekan pada pemberian motivasi kepada siswa untuk mau belajar, mengontrol kondisi kelas dan suara guru diperkuat lagi. Kemudian, pada tahap penutup peneliti memberikan pengayaan dan kesimpulan terkait seluruh rangkaian pembelajaran yang telah terlaksana.

Pada pertemuan kedua siklus II peneliti peneliti kembali memberikan tes untuk mengetahui hasil dari penerapan model pembelajaran Picture and Picture Berbantuan Kelompok Undian untuk meningkatkan hasil belajar siswa. Tahap yang dilakukan pada siklus II ini tidak jauh berbeda dengan tahap yang dilakukan pada siklus I, yang berbeda terletak pada materi, soal tes yang diberikan dan pemberian motivasi serta lebih memperketat pengkondisian kelas pada saat pembelajaran dan pemberian tes. 


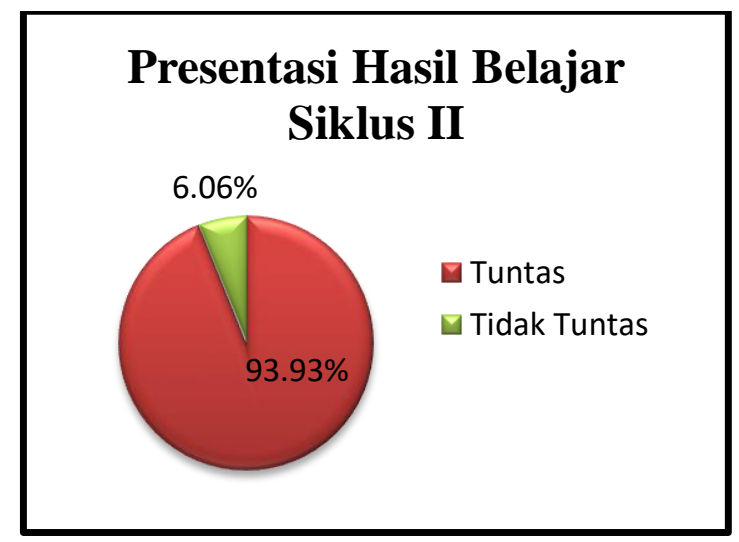

Diagram 2. Presentasi Hasil Belajar Siklus II

$$
P=\frac{\sum x}{n}
$$

$\mathrm{P}=$ Rata-rata nilai

$\sum \mathrm{x}=$ Jumlah nilai keseluruhan

$\mathrm{n}=$ Jumlah siswa

Tabel 2. Penentuan Keberhasilan Hasil Belajar

\begin{tabular}{ccc}
\hline Nilai Interval & Huruf & Kriteria \\
\hline$\geq 85$ & A & Sangat baik \\
\hline $75-84$ & B & Baik \\
\hline $65-74$ & C & Cukup \\
\hline $55-64$ & D & Kurang \\
\hline$\leq 54$ & E & Sangat kurang \\
\hline
\end{tabular}

Sumber:Adaptasi Jihad dan Setiorini (2007:136)

$$
P=\frac{2.776}{33}=84,12
$$

Penerapan model pembelajaran Picture and Picture berbantuan kelompok undian telah mampu meningkatkan hasil belajar. Sesuai dengan pendapat menurut Hamalik (dalam Dewi 2007.159) bahwa hasil belajar merupakan indikator adanya derajat perubahan tingkah laku siswa. Perubahan yang terjadi setelah penerapan model ini, yaitu dengan adannya perubahan tingkah laku yang dapat terukur dari hasil belajar yang telah tercapai, dengan perhitungan yang didapat adalah hanya terdapat 2 siswa atau 6,06\% yang tidak memenuhi standard KKM, sedangkan 31 siswa atau 93,93\% dengan nilai di atas KKM. Siswa yang belum mencapai ketuntasan pada siklus II, peneliti memberikan remedial sebagai tambahan nilai.

Data hasil belajar siswa pada siklus I dan siklus II dan hasil pengamatan dengan menggunakan model pembelajaran Picture and Picture berbantuan kelompok undian pada siswa kelas VIII B SMPN 2 Wagir. Perbandingan hasil belajar siswa Siklus I dan siklus II disajikan dalam bentuk tabel berikut ini:

Tabel 3. Ketercapaian Hasil Belajar Siswa Siklus I dan Siklus II

\begin{tabular}{cc}
\hline \multicolumn{3}{c}{ Ketercapaian Hasil Belajar } \\
\hline Siklus I & Siklus II \\
\hline 77,57 & 84,12 \\
\hline
\end{tabular}




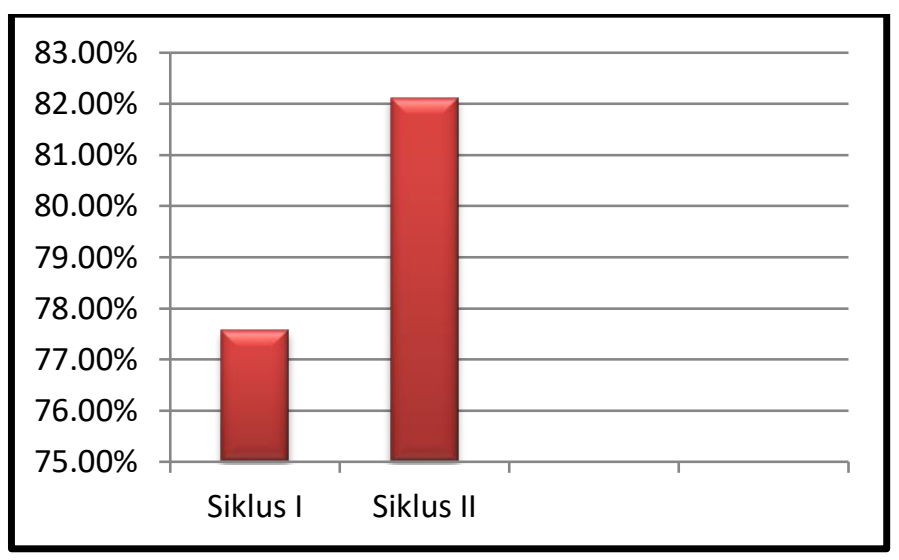

Grafik 3. Ketercapaian Hasil Belajar Siklus I dan Siklus II

Berdasarkan hasil ketercapaian hasil belajar siklus I yang telah mengalami peningkatan pada siklus II. Pada penerapan model pembelajaran Picture and Picture berbantuan kelompok undian telah berhasil meningkatkan hasil belajar dibuktikan dengan peningkatan nilai yang di dapatkan siswa.

Pada siklus II masih ditemukan 2 siswa yang belum mencapai Kriteria Ketuntasan Minimu (KKM), dengan beberapa pertimbangan akan nilai usaha dan penyempurnaan hasil penelitian penerapan model pembelajaran Picture and Picture berbantuan kelompok undian, yang dilakukan siswa maka guru, melakukan remedial untuk memperbaiki nilai siswa.

\section{Kesimpulan}

Berdasarkan hasil penelitian pada penerapan model pembelajaran Picture and Picture berbantuan kelompok undian telah berhasil meningkatkan hasil belajar dibuktikan dengan peningkatan nilai yang di dapatkan siswa. Peningkatan dari siklus I dengan rata-rata nilai siswa 76,96\% mengalami kenaikan pada siklus II dengan rata-rata siswa 84\% dengan kategori baik. Berdasarkan hasil penelitian yang diperoleh maka peneliti memberikan saran, diantaranya adalah: 1) Bagi Peneliti, model pembelajaran Picture and Picture berbantuan kelompok undian bisa dijadikan sebagai salah satu penambahan teori dari peneliti selanjutnya yang ingin meneliti model pembelajaran ini. 2) Bagi Guru, diharapkan dapat menerapkan model pembelajaran Picture and Picture berbantuan kelompok undian pada saat mengajar dalam upaya meningkatkan hasil belajar siswa khususnya pada mata pelajaran IPS. 3) Bagi Kepala Sekolah, penerapan pembelajaran model Picture And Picture berbantuan Kelompok Undian dan siswa diberi kesempatan untuk terlibat aktif dalam proses kegiatan belajar mengajar, sehingga pengetahuan yang diperoleh dapat meningkatkan hasil belajar. 4) Bagi Siswa, diharapkan ikut aktif dan berpartisipasi dalam kegiatan diskusi tanpa harus menggantungkan pada orang lain. Disamping itu harus memperhatikan penjelasan guru agar informasi yang diberikan dapat diterima dengan baik karena model pembelajaran ini meminta siswa untuk bisa menyamakan teori dengan keadaan yang nyata di lingkungan sehingga berbantuan media gambar, sehingga siswa di lebih aktif, kreatif dalam mengikuti pembelajaran serta mampu membangun pengetahuannya sendiri untuk meningkatkan hasil belajar. 


\section{Ucapan Terimahkasih}

Penulis berterimahkasih kepada Universitas Kanjuruhan Malang, Program Studi Pendidikan Geografi yang telah menyelenggarakan penulisan hasil penelitian ini, penulis juga menyampaikan terimahkasih kepada Lembaga Pendidikan SMP Negeri 2 Wagir yang telah mengijikan penulis untuk meneliti tentang model pembelajaran Picture And Picture berbantuan Kelompok Undian. Penulis juga menyampaikan terimahkasih banyak kepada orang tua dan saudara yang telah memberikan dukungan khususnya pada finansial serta semua sahabat dan kerabat yang telah mendukung dengan cara mereka masing-masing.

\section{Daftar Pustaka}

Dewi F. K. 2013. Penerapan Model Picture And Picture Untuk Meningkatkan Keterampilan Menulis Deskripsi Pada Kelas II SDN Bringin 02 Semarang. https://jurnal.untan.ac.id. Diakses 30 Juni 2018.

Juniarti, Yohanes Bahari dan Wanto Riva'ie. 2015. Faktor Penyebab Menurunnya Hasil Belajar Siswa Pada Pembelajaran Sosiologi SMA. https://jurnal.untan.ac.id. Diakses 30 Juni 2018

Kurnia Utin, Herkulana dan F.Y. Khosmas. 2015. Pengaruh Fasilitas Dan Minat Belajar Terhadap Hasil Belajar Mata Pelajaran Pemasaran Siswa SMA 1 Pontianak. https://jurnal.untan.ac.id. Diakses 30 Juni 2018. 